SYSTEMATICS, MORPHOLOGY AND PHYSIOLOGY

\title{
Evaluation of the RAPD Profiles from Different Body Parts of Euglossa pleosticta Dressler Male Bees (Hymenoptera: Apidae, Euglossina)
}

\author{
Amália N.T. Pascual, Karen M. Suzuki, Fernanda S. Almeida, Leda M.K. Sodré and \\ Silvia H. Sofia
}

Depto. Biologia Geral, Univ. Estadual de Londrina, 6001, 86051-990,Londrina, PR, shsofia@uel.br

Neotropical Entomology 35(6):811-817 (2006)

Avaliação dos Perfis de RAPD de Diferentes Partes do Corpo de Machos de Abelhas Euglossa pleosticta Dressler (Hymenoptera: Apidae, Euglossina)

\begin{abstract}
RESUMO - Na literatura atual, são escassas as informações sobre qual a parte do corpo do inseto adulto é mais adequada para a extração de DNA genômico para estudos de análises genéticas baseadas em marcadores de DNA. Neste estudo, foram analisados os perfis de RAPD produzidos a partir da amplificação do DNA genômico extraído de partes distintas do corpo (cabeça, pernas, tórax + asas e abdome) de 12 machos de Euglossa pleosticta Dressler. Do total de bandas analisadas, 9,0\% não mostraram repetibilidade. As porcentagens de variação de bandas em relação às diferentes partes do corpo das abelhas foram: $1,1 \%$ (cabeça); $0,4 \%$ (pernas); $0,8 \%$ (tórax/asas) e 6,7\% (abdome). A maior variação observada $\left(\chi_{\text {para uma amostra }}^{2}=10,27 ; \mathrm{gl}=1 ; \mathrm{P}<0,01\right)$, nos perfis eletroforéticos de RAPD, produzidos nas amplificações do DNA extraído do abdome de machos euglossíneos sugere que essa parte do corpo de insetos adultos deve ser evitada em procedimentos de extração de DNA. De modo diverso, a baixa variação entre os perfis de RAPD obtidos a partir das amplificações de DNA genômico extraído da cabeça, pernas e tórax/asas das abelhas indica que todas essas partes do corpo de machos euglossíneos são igualmente úteis e confiáveis para serem utilizadas para a extração e a amplificação do DNA genômico.
\end{abstract}

PALAVRAS-CHAVE: Apoidea, Euglossini, abelha de orquídea, marcador molecular

\begin{abstract}
In the current literature, information is scarce on which part of the adult insect body is suitable for isolation of genomic DNA for genetic analysis based on DNA-markers. In this study, we evaluated RAPD profiles generated from total genomic DNA isolated from distinct body parts (head, legs, thorax + wings and abdomen) of 12 males of Euglossa pleosticta Dressler. From the total of bands analyzed, 9.0\% did not show reproducibility. Percent variations of bands in each body segment were: $1.1 \%$ (head); $0.4 \%$ (legs); $0.8 \%$ (thorax/wings) and 6.7\% (abdomen). The much higher variation $\left(\chi_{\text {one sample }}^{2}=10.27 ; \mathrm{df}=1 ; \mathrm{P}<0.01\right)$ in the RAPD profiles obtained by using DNA isolated from abdomen of the euglossine males suggests that this body part of adult insects should be avoided in DNA extraction procedures. Conversely, the low variation among the RAPD profiles obtained from amplifications of genomic DNA extracted from head, legs and thorax/wings indicates that all these body parts of male bees are equally useful and secure for using in isolation and amplification procedures of total genomic DNA.
\end{abstract}

KEY WORDS: Apoidea, Euglossini, orchid bee, euglossine bee, molecular marker

Recent advances in molecular technology have greatly increased the number of techniques used in genetic studies based on the total genomic DNA analysis. Many of these techniques have been widely employed in genetic analysis of a variety of adult insects (Carvalho \& Vieira 2001, Watts et al. 2004, Keyghobadi et al. 2005, Sofia et al. 2005). However, when total genomic DNA is extracted from adult insect body parts, a worrying aspect of the genetic analysis can be the incidence of spurious DNA due, for instance, to the presence of commensal organisms associated with the material under study (Rabouam et al. 1999). In researches involving adult bees, or even adult insects in general, the most frequent sources of such DNA are pollen and microorganisms on the insect integument.

Another emerging question when genetic analysis involves adult insects is which part of the insect body is suitable for isolation of the genomic DNA for obtaining reliable DNAmarkers. Actually, until this moment there is a gap in the literature concerning this question and, consequently, a wide variation in methods for DNA extraction of adult insects can 
be found, including DNA isolation from head (Harper et al. 2003), legs (Watts et al. 2004), wings or the whole insect (Keyghobadi et al. 2005).

Among the most known techniques based on the analysis of total genomic DNA, RAPD (Random Amplified Polymorphic DNA) has been described as a simple and easy method of detecting polymorphism based on the amplification of random DNA segments with single primers of arbitrary nucleotide sequence (Williams et al. 1990). Because RAPD is a fast and technically simple method, requiring minimal amounts of DNA and no previous knowledge of the genome (Williams et al. 1990, Ayliffe et al. 1994), it has been used in many different biological approaches, such as mapping (Martin et al. 1991), identification of species or subspecies (Hillis et al. 1996), parentage analysis (Hunt \& Page 1992) and evaluation of anthropogenic stress in aquatic ecosystems (Bickham et al. 2000). In addition, RAPD markers are relatively inexpensive to produce and can be visualized and scored on regular agarose gels (Kjølner et al. 2004).

On the other hand, according to several authors, the reproducibility between RAPD reactions can be hard to maintain (Ayliffe et al. 1994, Rabouam et al. 1999) since small changes in reaction conditions, such as the type of DNA polymerase used, template DNA concentration, magnesium concentration and temperature-profiling characteristic of the thermalcycler can produce changes in RAPD bands profiles (Pérez et al. 1998). Thus, possible solutions proposed to minimize problems in RAPD reproducibility include a careful optimization of the concentrations of components in the reaction mixture and of the amplification conditions of the thermal cycler, which should be consistently maintained throughout the study (Chiappero \& Gardenal 2001).

In this context, our central aim was to investigate the occurrence of variations in RAPD profiles produced by amplification of total genomic DNA isolated from different body parts of adult male bees.

\section{Material and Methods}

Sample collections. Samplings were carried out during March of 2004, at Mata dos Godoy State Park, a remnant of Atlantic Rainforest located in northern Paraná State, southern Brazil. After being attracted to scent baits of eucalyptol, 12 males of Euglossa pleosticta Dressler were collected with an insect net, placed individually in plastic tubes, transported alive to the laboratory and stored frozen $\left(-20^{\circ} \mathrm{C}\right)$ until DNA extraction. All bees were identified by S. H. Sofia and voucher specimens are deposited at the Museu de Zoologia, Universidade Estadual de Londrina (MZUEL).

DNA extraction and RAPD analysis. The following insect body parts were separated for subsequent RAPD analysis: a) head, b) six legs, c) thorax plus wings and d) abdomen. Prior to DNA isolation, bees were submitted to two distinct pre-treatments, to remove exogenous material (e.g. fungal spores or grains of pollen) possibly attached to the bee integument, as follows: each body part of bees was rinsed individually in a sterilized plate with distilled water or $70 \%$ alcohol. The methodology of total genomic DNA extraction used was based on Sofia et al. (2005). DNA concentration was determined in a fluorometer (200 DyNA Quant, Hoefer), using the dye Hoechst 33258, and then all DNA samples were diluted to a standard concentration $(5 \mathrm{ng} / \mu \mathrm{l})$. All isolates were stored at $-20^{\circ} \mathrm{C}$.

The RAPD profiles were generated from total genomic DNA according to Sofia et al. (2005). Amplification reactions were carried out in a final volume of $15 \mu$ containing 15-25 ng of template DNA, $250 \mu \mathrm{M}$ dNTPs (Pharmacia), $0.3 \mu \mathrm{M}$ of ten-nucleotide primer (Operon Technologies, Alameda, CA, USA), $4.0 \mathrm{mM} \mathrm{MgCl}$ and $0.6 \mu \mathrm{l}$ (3 units) of DNA polymerase in the reaction buffer supplied. The following primers were used in the analysis: OPX-04, OPX-06, OPX16 and OPAM-14. Control reactions were run containing all components except genomic DNA. DNA amplifications were carried out in a PTC-100, MJ Research thermal cycler and the amplification protocol consisted of 4 min denaturation at $92^{\circ} \mathrm{C}$ followed by 40 cycles of 40 at $92^{\circ} \mathrm{C}, 1.5 \mathrm{~min}$ at $40^{\circ} \mathrm{C}$, and $2 \mathrm{~min}$ at $72^{\circ} \mathrm{C}$, and a final cycle of $5 \mathrm{~min}$ at $72^{\circ} \mathrm{C}$.

Samples of $15 \mu \mathrm{l}$ of the amplification products were separated by electrophoresis on $1.4 \%$ agarose gels with TBE buffer $(0.89 \mathrm{mM}$ Tris, $0.89 \mathrm{mM}$ boric acid, $2 \mathrm{mM}$ EDTA

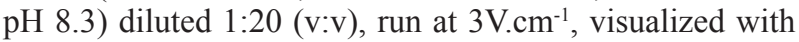
ethidium bromide staining and photographed under UV light with the Kodak Digital Science system (EDAS120).

Data analysis. To test differences between the two pretreatments, two groups of treatments were made. In the first, head and legs from the same bee were washed, individually, in distilled water, while thorax/wings and abdomen were washed, separately, with $70 \%$ alcohol. In the second group, these treatments were inverted, i.e., head and legs from the same bee were washed individually with alcohol $70 \%$, while thorax/wings and abdomen were rinsed, independently, with distilled water.

Comparative analyses were carried out by placing all samples on the same gel. Additionally, the samples (head, legs, thorax/wings and abdomen) from the same individual were placed side by side on the gel. RAPD marker profiles were determined by direct comparison of the amplified DNA electrophoretic profiles, and each sample was scored for the presence or absence of amplification products (binary variable).

The chi-squared test $(2 \times 2)$ was applied to compare the two pre-treatments (washing in alcohol or water). An onesample $\chi^{2}$ test was employed to compare possible differences in RAPD profiles from different groups of body parts, as follows: 1) head; 2) legs; 3) thorax +wings and, 4) abdomen submitted to each pre-treatment. Values were considered different when $\mathrm{P}<0.05$ (Siegel 1981).

The estimate of reproducibility among body samples isolated from the same bee $\left(\mathrm{R}_{\mathrm{xywz}}\right)$ was calculated by dividing the number of bands common to all four segments (x, y, w, z) in the RAPD profile $\left(\mathrm{n}_{\mathrm{xywz}}\right)$ by the average number of scored bands for all body parts, viz.: $\mathrm{R}_{\mathrm{xywz}}=4 \mathrm{n}_{\mathrm{xywz}} /\left(\mathrm{n}_{\mathrm{x}}+\mathrm{n}_{\mathrm{y}}+\mathrm{n}_{\mathrm{w}}+\right.$ $n_{z}$ ), where $n_{x}, n_{y}, n_{w}$ and $n_{z}$ represent the number of RAPD bands in head, legs, wings + thorax and abdomen, respectively (Pérez et al. 1998). Samples that partially or totally failed in the amplification were not included in the analysis. 
After calculation of the reproducibility index for each bee with each primer, a mean value of the reproducibility including the 12 individuals analyzed was estimated.

A pair-wise similarity matrix was constructed using the Jaccard $(J)$ index (Sneath \& Sokal 1973). On the basis of the $J$-values of the samples, the UPGMA clustering method was followed, employing the NTSYS-PC package (Rohlf 2000 ) to generate a dendrogram of similarity. To evaluate the robustness of the groupings formed, a bootstrap analysis, with 1000 replications, was performed using the Bood software program (Coelho 2000).

DNA fragment sizes were estimated by comparison to the standard Ladder $100 \mathrm{bp}$ (Biotools), and by using the GEL software.

\section{Results}

The RAPD marker patterns were assessed in E. pleosticta DNA extracted from different body parts of 12 males, totalling 48 samples. The largest number of bands was found with primer OPX-06. The four primers used produced from 9 to 25 bands, which varied from 371 to 4053 bp (Table 1). Reproducibility of the results was tested with primer OPX16 and no variation was found. The average reproducibility index estimated for each primer varied from 0.92 to 0.98 (Table 1), revealing a high similarity among the profiles for each body part from the same bee analyzed.

Fig. 1 shows the RAPD profiles for 48 samples amplified with primers OPX-06, OPX-04 and OP-AM14. In these profiles, it is possible to observe the high reproducibility among the four different body parts from each bee. Also, a negative control from RAPD reactions amplified with the primer OPAM-14 produced some faint bands, which were mostly different from bands in the amplified reactions (Fig. 1).

The comparative analysis of RAPD profiles revealed no significant difference $\left(\chi^{2}=2.44, \mathrm{df}=1 ; \mathrm{P}>0.05\right)$ between the two pre-treatments (water or alcohol). Therefore, to reveal any differences between the RAPD profiles from the four different groups of body parts (head, legs, thorax + wings, abdomen), both pre-treatments were grouped and the profiles produced by each body part were compared for each bee individually.

Out of a total of 476 fragments analyzed, $9.0 \%(n=43)$ did not show reproducibility (Table 2). Percentages of variation in the reproducibility for the different body segments were: $1.05 \%$ (head); $0.42 \%$ (legs); $0.84 \%$ (thorax/wings) and $6.72 \%$ (abdomen). Application of the $\chi^{2}$ test (one sample) revealed significant differences among these occurrences of variations $\left(\chi^{2}=56.44, \mathrm{df}=3 ; \mathrm{P}<0.001\right)$, indicating some variation in amplified products from the same individual.

The dendrogram of similarity obtained by applying the Jaccard index and the UPGMA method revealed that different parts from the same individual clustered together, showing coefficients ranging from 0.84 to 1.0 (Fig. 2). Bootstrap values for the UPGMA tree were generally very high ( $>$ 95\%) for the branches clustering different body parts of the same bee, reflecting a high robustness of these branches. The lowest value observed $(0.84)$ occurred between the abdomen from individual 1 and the other body segments of this bee. However, for the majority of individuals analyzed, the values of similarity among the different body parts from the same bee were above 0.9 , indicating the high reproducibility of RAPD technique. After clustering together, the four body parts from the same bee formed new clusters with other individuals. The similarity among individuals ranged from 0.60 to 0.81 .

\section{Discussion}

Among the 43 occurrences that did not show complete reproducibility four $(9.3 \%)$ were due to the presence of bands that were absent in other samples (Table 2), and 39 occurrences $(90.7 \%)$ corresponded to the absence of bands in one or two samples from the same individual.

Our results showed a high reproducibility of RAPD profiles produced by different body parts from the same bee (Fig. 1 and Table 2), suggesting that when optimization and standardization of RAPD technique are undertaken, reproducible profiles can be satisfactorily achieved. The differences in repeatability shown by body segments $\left(\chi^{2}=\right.$ 56.44 , df $=3 ; \mathrm{P}<0.001$ ) were possibly due to variations in abdomen profiles, since this body part showed a lower repeatability $(6.7 \%$ of variation) than the other insect body segments. Besides, when variation in abdomen profiles $(\mathrm{n}=$ 32) was compared to the total number of variations shown by other body parts $(\mathrm{n}=11)$, a significant difference was found $\left(\chi_{\text {one sample }}^{2}=10.27, \mathrm{df}=1 ; \mathrm{P}<0.01\right)$. In part, the greater variation in abdomen profiles may be attributed to low reproducibility shown by the abdomen from individuals 1 and 4 (Table 2). In part, in both situations, DNA obtained from abdomen might have suffered damages during the isolation phase, since these samples showed several absences in RAPD products obtained

Table 1. Nucleotide sequences from primers used in RAPD reactions, number of amplified fragments and range of fragment sizes produced by different primers and average reproducibility estimates.

\begin{tabular}{lcccc}
\hline Primer & Nucleotide sequence & $\begin{array}{c}\text { Number of } \\
\text { fragments }\end{array}$ & $\begin{array}{c}\text { Range of fragment } \\
\text { size (bp) }\end{array}$ & $\begin{array}{c}\text { Reproducibility } \\
\left(R_{x y w z}\right)\end{array}$ \\
\hline OPX-04 & 5' CCGCTACCGA 3' & 14 & $524-3370$ & 0.95 \\
OPX-06 & 5' ACGCCAGAGG 3' & 25 & $371-4053$ & 0.92 \\
OPX-16 & 5' CTCTGTTCGG 3' & 9 & $706-2366$ & 0.98 \\
OPAM-14 & 5' TGGTTGCGGA 3' & 21 & $374-2806$ & 0.94 \\
\hline
\end{tabular}



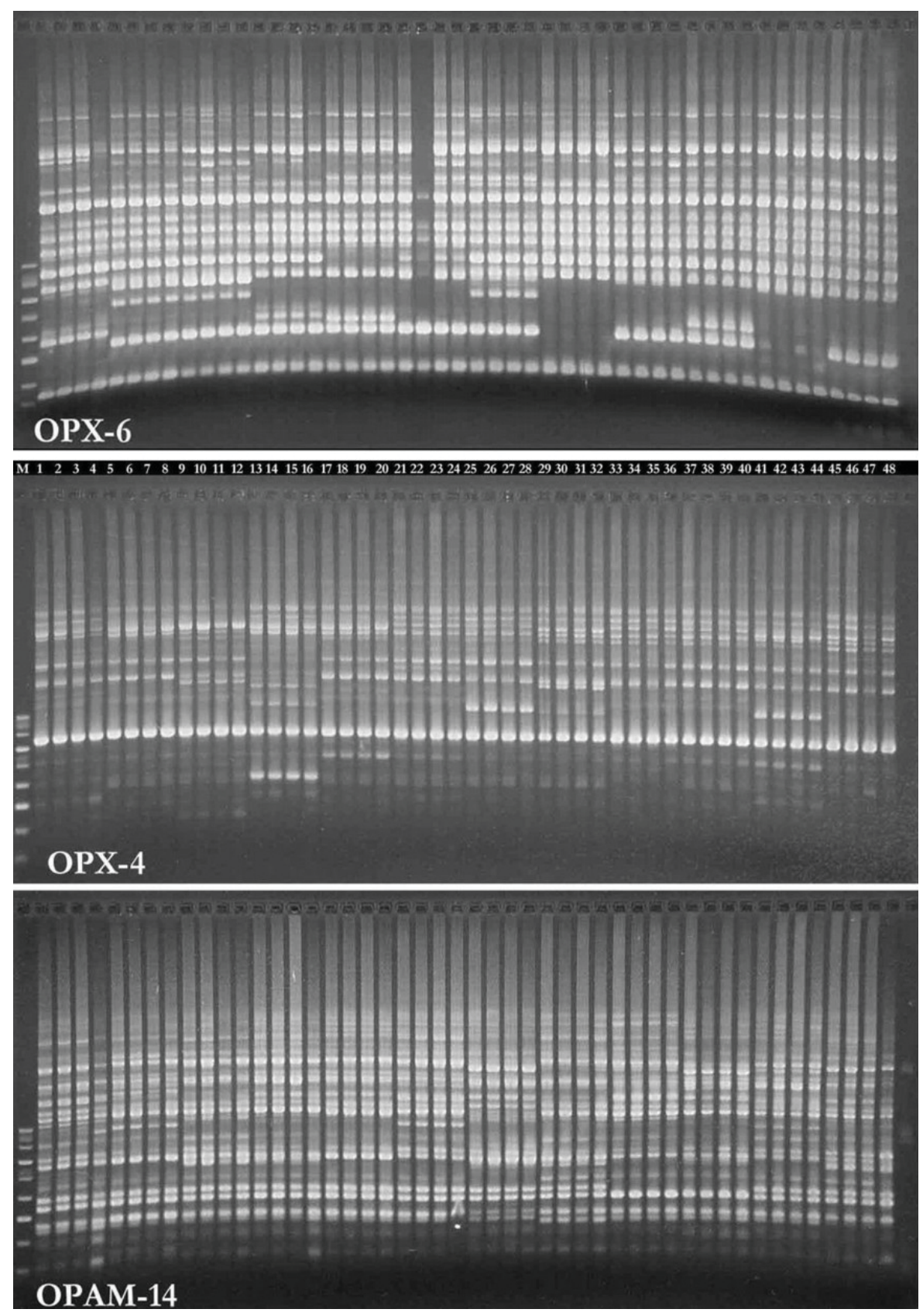

Fig. 1. RAPD profiles of E. pleosticta, from different body segments, amplified with primers OP-X6, OP-X4 and OP-AM14. Lane $\mathrm{M}=100 \mathrm{bp}$ molecular weight marker. Samples of the same bee were arranged in the gel as follows: head, legs, thorax + wings and abdomen. Lanes: 1, 2, 5, 6, 9, 10,13, 14, 17, 18, 21, 22, 27, 28, 31, 32, 35, 36, 39, 40, 43, 44, 47, 48 = parts of bees washed with water. Lanes: $3,4,7,8,11,12,15,16,19,20,23,24,25,26,29,30,33,34,37,38,41,42,45,46=$ parts of bees washed with alcohol. Last lane $=$ control.

with all four primers used in amplifications reactions (Table 2 and Fig. 1). Regardless of their feeding habits, all insects possess a range of enzymes in the midgut, located in the abdomen, where digestion occurs (Chapman 1982). According to Walker et al. (1998), proteases are present in the gut of adult insects and show activity over a wide $\mathrm{pH}$ range. Thus, some of the variations in abdomen RAPD profiles may be attributed to the action of digestive enzymes (eg. esterase) on DNA during the extraction stage.

Rabouam et al. (1999) attributed artefactual RAPD polymorphism to the presence of commensal organisms and fragment rearrangements during PCR amplification. 
Table 2. Features of the RAPD fragments produced by amplification of genomic DNA isolated from individual body parts of E. pleosticta males that did not show reproducibility with other body parts.

\begin{tabular}{|c|c|c|c|c|c|}
\hline Number of bee & Fragment name & Body part & Size (bp) of RAPD fragment & Kind of variation & Treatment \\
\hline 1 & B2-X06 & Abdomen & 3963 & Absence & A \\
\hline 1 & B7-X06 & Abdomen & 2566 & Absence & A \\
\hline 1 & B8-X06 & Thorax & 2501 & Absence & A \\
\hline 1 & B8-X06 & Abdomen & 2501 & Absence & A \\
\hline 1 & B11-X06 & Abdomen & 2023 & Absence & A \\
\hline 1 & B1-AM14 & Abdomen & 2806 & Absence & A \\
\hline 1 & B7-AM14 & Abdomen & 1696 & Absence & A \\
\hline 1 & B12-AM14 & Abdomen & 1075 & Presence & $\mathrm{A}$ \\
\hline 2 & B2-AM14 & Abdomen & 2427 & Absence & A \\
\hline 2 & B14-AM14 & Leg & 846 & Absence & $\mathrm{W}$ \\
\hline 3 & B1-X04 & Abdomen & 3370 & Absence & A \\
\hline 3 & B1-X06 & Abdomen & 4053 & Absence & $\mathrm{A}$ \\
\hline 3 & B2-X06 & Abdomen & 3963 & Absence & A \\
\hline 3 & B3-X06 & Abdomen & 3648 & Absence & $\mathrm{A}$ \\
\hline 3 & B11-X06 & Abdomen & 2023 & Absence & A \\
\hline 3 & B13-X06 & Abdomen & 1471 & Absence & A \\
\hline 4 & B2-X06 & Abdomen & 3963 & Absence & A \\
\hline 4 & B4-X06 & Abdomen & 3501 & Absence & A \\
\hline 4 & B5-X06 & Abdomen & 3282 & Absence & A \\
\hline 4 & B8-X06 & Head & 2501 & Absence & $\mathrm{W}$ \\
\hline 4 & B8-X06 & Abdomen & 2501 & Absence & A \\
\hline 4 & B16-X06 & Head & 1103 & Absence & W \\
\hline 4 & B1-AM14 & Abdomen & 2806 & Absence & A \\
\hline 4 & B14-AM14 & Abdomen & 846 & Absence & A \\
\hline 4 & B17-AM14 & Abdomen & 605 & Absence & A \\
\hline 5 & B2-X16 & Head & 2207 & Absence & W \\
\hline 5 & B2-X16 & Abdomen & 2207 & Absence & A \\
\hline 5 & B17-AM14 & Thorax & 605 & Presence & A \\
\hline 5 & B17-AM14 & Abdomen & 605 & Presence & A \\
\hline 6 & B5-X06 & Head & 3282 & Absence & $\mathrm{W}$ \\
\hline 7 & B9-X06 & Thorax & 2477 & Absence & $\mathrm{W}$ \\
\hline 7 & B20-X06 & Leg & 862 & Absence & A \\
\hline 7 & B20-X06 & Abdomen & 862 & Absence & W \\
\hline 9 & B7-X04 & Thorax & 1868 & Absence & W \\
\hline 9 & B13-AM14 & Abdomen & 977 & Absence & W \\
\hline 9 & B17-AM14 & Abdomen & 605 & Absence & W \\
\hline 11 & B6-X04 & Abdomen & 2438 & Absence & W \\
\hline 11 & B5-X06 & Head & 3282 & Absence & A \\
\hline 11 & B9-X06 & Abdomen & 2477 & Presence & W \\
\hline 12 & B6-AM14 & Abdomen & 1821 & Absence & W \\
\hline 12 & B7-AM14 & Abdomen & 1696 & Absence & W \\
\hline 12 & B15-AM14 & Abdomen & 769 & Absence & W \\
\hline 12 & B15-AM14 & Abdomen & 769 & Absence & W \\
\hline
\end{tabular}

$\mathrm{W}=$ water; $\mathrm{A}=$ alcohol; the number of bee corresponds to its position on the gel; fragment name is represented by number of band (ex. B15 = $15^{\text {th }}$ band), showed in descending size, followed by the corresponding primer. 


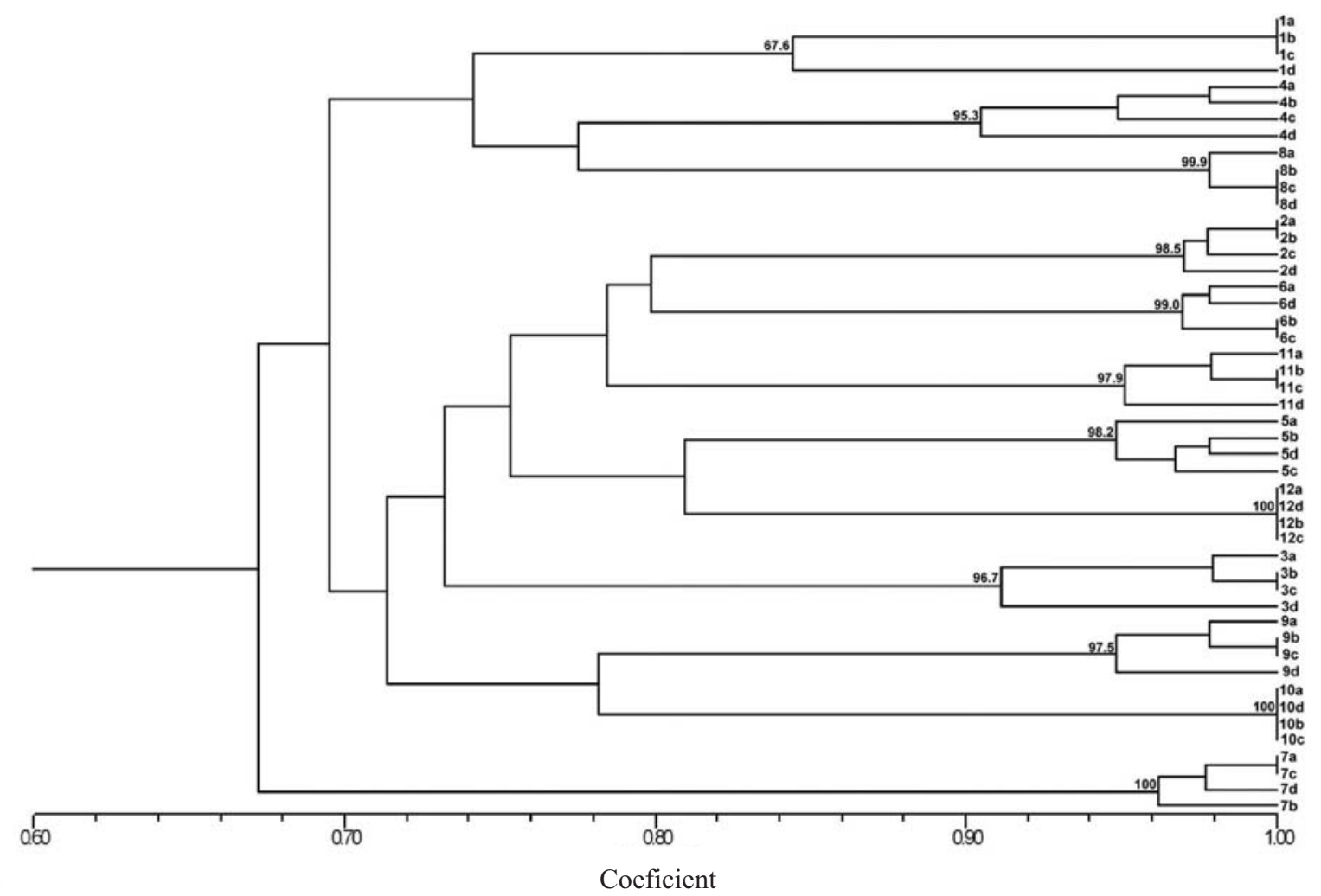

Fig. 2. Dendrogram of genetic similarity constructed using the Jaccard coefficient and the UPGMA method for different body parts of 12 males of E. pleosticta. Numbers from 1 to 12 represent each bee. a $=$ head, $\mathrm{b}=\operatorname{legs,} \mathrm{c}=$ thorax + wings and $\mathrm{d}=$ abdomen. Numbers at the nodes represent bootstrap values generated by 1000 replications.

According to these authors, artefacts accounted for $50-75 \%$ of all the RAPD fragments obtained, and they concluded that it is impossible to estimate the degree of DNA polymorphism by RAPD studies. Our results suggest that the absence of reproducibility did not result from exogenous material, such as pollen or microorganisms, in the gut of bees, since only in four cases additional bands were observed in RAPD profiles from the same individual (Table 2). In contrast to males of eusocial Apis mellifera L. (Hymenoptera: Apidae), which stay inside the nest for several days after emergence (Winston 1987), most reports indicate that euglossine males leave the nest promptly and do not return (Dodson 1966). During adult life, euglossine males need only nectar supplies (Dodson 1966), which provide energy for their activities. For this reason, the presence of pollen in the digestive tube of euglossine males is very improbable.

The four additional bands produced in RAPD reactions with primers OPX-06 and OPAM-14 (Table 2) probably are artefacts, since such bands may arise from heteroduplex formation between amplified products (Ayliffe et al. 1994) or from other secondary artifacts (Hadrys et al. 1992). Also, the few faint bands observed in the negative control, amplified with primer OPAM-14 (Fig. 1) were attributed to heteroduplex molecules (Ayliffe et al. 1994). The presence of such bands in the negative control were already reported by other authors (Williams et al. 1990, Pérez et al. 1998).
Overall, the current results indicate that the much higher variation observed in abdomen profiles $\left(\chi_{\text {one sample }}^{2}=\right.$ 10.27 ; $\mathrm{df}=1 ; \mathrm{P}<0.01)$ suggests that this body segment of bees and probably other insects should be avoided in DNA extraction procedures. Conversely, the low variation among RAPD profiles obtained from amplifications of head, legs and thorax/wings indicates that all these body parts of male bees are equally useful and secure for using in isolation and amplification procedures of total genomic DNA.

\section{Acknowledgments}

The authors are grateful to IAP (Instituto Ambiental do Paraná) and IBAMA (Instituto Brasileiro do Meio Ambiente) for permission to collect male euglossine bees at Parque Estadual Mata dos Godoy and to the anonymous reviwers for comments on the manuscript. ANT Pascual and KM Suzuki thank CAPES for providing the scholarship. This study was supported by grants provided by FBPN (Fundação O Boticário de Proteção à Natureza) and Fundação Araucária and ProDiCi/UEL.

\section{References}

Ayliffe, M.A,. G.J. Lawrence, J.G. Ellis \& A.J. Prior. 1994. Heteroduplex molecules formed between allelic sequences cause 
nonparental RAPD bands. Nucleic Acids Res. 22: 1632-1636.

Bickham, J.W., S. Sandhu, P.D.N. Hebert, L. Chickhi \& R. Athwal. 2000. Effects of chemical contaminants on genetic diversity in natural populations: Implications for biomonitoring and ecotoxicology. Mutat. Res. 463: 33-51.

Carvalho, A.O.R. \& L.G.E. Vieira. 2001. Determinação das condições ótimas para análises de PCR-RAPD em Atta sexdens rubropilosa Forel (Hymenopera: Formicidae). Neotrop. Entomol. 30: 593-600.

Chapman, R.F. 1982. The insects: Structure and function, 3rd ed. London, Hodder and Stoughton Ltd., 934p.

Chiappero, M.B. \& C.N. Gardenal. 2001. Inheritance of random amplified polymorphic DNA (RAPD-PCR) markers and their use in population studies of Calomys musculinus (Rodentia, Muridae), the reservoir of Argentine Hemorrhagic Fever. Hereditas (Lund) 135: 85-93.

Coelho, A.S.G. 2000. BOOD: Avaliação de dendrogramas baseados em estimativas de distâncias/similaridades genéticas através do procedimento de bootstrap. Software, Goiânia, UFG.

Dodson, C.H. 1966. Ethology of some bees of the tribe Euglossini (Hymenoptera: Apidae). J. Kans. Entomol. Soc. 39: 607-629.

Hadrys, H., M. Balick \& B. Schierwater. 1992. Applications of random amplified polymorphic DNA (RAPD) in molecular ecology. Mol. Ecol. 1: 55-63.

Harper, G.L., N. McClean \& D. Goulson. 2003. Microsatellite markers to assess the influence of population size, isolation and demographic change in the genetic structure of the UK butterfly Polyommatus bellargus. Mol. Ecol. 12: 3349-3357.

Hillis, D.M., C. Moritz \& B.K. Mable (eds). 1996. Molecular systematics, 2nd ed. Sunderland, Cumbria, Sinauer Associates, Inc., $655 \mathrm{p}$.

Hunt, G.J. \& and R.E. Page Jr. 1992. Patterns of inheritance with RAPD molecular markers reveal novel types of polymorphism in the honey bee. Theor. Appl. Genet. 85: 15-20.

Keyghobadi, N., J. Roland \& C. Strobeck. 2005. Genetic differentiation and gene flow among populations of the alpine butterfly, Parnassius smintheus, vary with landscape connectivity. Mol. Ecol. 14: 1897-1909.

KjØlner, S., S.M. Såstad, P. Taberlet \& C. Brochmann. 2004. Amplified fragment length polymorphism versus random amplified polymorphic DNA markers: Clonal diversity in Saxifraga cernua. Mol. Ecol. 13: 81-86.
Martin, G.B., J.G.K. Williams \& and S.D. Tanskley. 1991. Rapid identification of markers linked to a Pseudomonas resistance gene in tomato by using random primers and near-isogenic lines. Proc. Natl. Acad. Sci. U.S.A. 88: 2336-2340.

Pérez, T., J.A. Albornoz \& A. Domênguez. 1998. An evaluation of RAPD fragment reproducibility and nature. Mol. Ecol. 7: 1347-1357.

Rabouam, C., A.M. Comes, V. Bretagnolle, J-F. Humbert, G. Periquet \& Y. Bigot. 1999. Features of DNA fragments obtained by random amplified polymorphic DNA (RAPD) assays. Mol. Ecol. 8: 493-503.

Rohlf, F.J. 2000. NTSYSpc, numeral taxonomy and multivariate analysis system, version 2.1. Exeter Software, Applier Biostatistics, Setauket, New York.

Siegel, S. 1981. Estatística não-paramétrica: Para as ciências do comportamento. São Paulo, Ed. McGraw-Hill do Brasil, Ltda., $350 \mathrm{p}$.

Sneath, P.H.A. \& R.R. Sokal. 1973. Numerical taxonomy: The principles and practice of numerical classification. San Francisco, California, WH Freeman, 573p.

Sofia, S.H. F.M. Paula, A.M. Santos, F.S. Almeida \& L.M.K. Sodré. 2005. Genetic structure analysis of Eufriesea violacea (Hymenoptera, Apidae) populations from southern Brazilian Atlantic Forest remnants Genet. Mol. Biol. 28: 479-484.

Walker, A.J., L. Ford, M.E.N. Majerus, I.E. Geoghegan, N. Birch, J.A. Gatehouse \& A.M.R. Gatehouse. 1998. Characterisation of the mid-gut digestive proteinase activity of the two-spot ladybird (Adalia bipuntacta $\mathrm{L}$.) and its sensitivity to proteinase inhibitors. Insect Biochem. Mol. Biol. 28: 173-180.

Watts, P.C., R. Rouquette, I.J. Saccheri, S.J. Kemp \& D.J. Thompson. 2004. Molecular and ecological evidence for small-scale isolation by distance in an endangered damselfly, Coenagrium mercuriale. Mol. Ecol. 13: 2931-2945.

Williams, J.G.K., A.R. Kubelik, K.L. Livak \& S.V. Tingey. 1990. DNA polymorphism amplified by arbitrary primers are useful as genetic markers. Nucleic Acids Res. 18: 6531-6535.

Winston, M.L. 1987. The biology of the honeybee. Cambridge, Massachussets, Harvard University Press, 281p.

Received 03/III/06. Accepted 04/VII/06. 